\title{
Exploration of NPK Activity Showing Chromium Resistant Bacteria from Sukinda Mining Area
}

\author{
S. Pattnaik ${ }^{1}$, D. Dash ${ }^{2}$ and D.P. Samantaray ${ }^{1 *}$ \\ ${ }^{1}$ Department of Microbiology, ${ }^{2}$ Department of Botany, CBSH, OUAT, \\ Bhubaneswar-3, Odisha-751003, India \\ *Corresponding author
}

\section{A B S T R A C T}

\section{Keywords}

Hexavalent chromium, Morphophysiological, Solubility index, Detoxification.

Article Info

Accepted:

07 October 2017

Available Online:

10 December 2017
The goal of the study is to explore potential chromium resistant and nitrogen fixing, phosphate \& potassium solubilizing bacteria from Sukinda mining area for bioremediation of $\mathrm{Cr}$ (VI) contaminated soil. In toto 25 bacteria were isolated, among them 14 isolates showed resistance to hexavalent chromium. Moreover, bacterial isolates such as Paenibacillus sp. CTSI-01, Micrococcus sp. CTWI-03 and Enterobacter sp. CTWI-06 were able to tolerate $3500 \mathrm{ppm}$ of $\mathrm{Cr}$ (VI) concentration. The bacterial isolates were affiliated to the genus such as Bacillus, Paenibacillus, Brevibacillus, Acinetobacter, Enterobacter, Micrococcus and Staphylococcus by morpho-physiological characterizations. Interestingly, amongst 14 chromium resistant bacteria, three isolates such as Micrococcus sp. CTSI-06, Enterobacter sp. CTWI-06 and Acinetobacter sp. CTWI-07 depicted nitrogen fixation, phosphate and potassium solubilization capability as revealed from solubility index. Thus, these potential chromium resistant and NPK activity showing locally isolated bacterial strains may be used for detoxification of $\mathrm{Cr}$ (VI) as well as to increase nutrient availability of chromium contaminated soils.

\section{Introduction}

Rapid industrialization coupled with exponential increase in use of toxic chemicals and mining activities has not only resulted in global environmental deterioration, but also has drawn attention of scientists for an effective measure to control pollution. The Sukinda mining zone, Odisha is one of the chromium contaminated area due to chromite mining since more than four decades. As a matter of fact, the flora, fauna along with human population of the mining area are adversely affected due to $\mathrm{Cr}$ (VI) pollution (Mishra et al., 2010). Moreover, mining activities are major causes of soil texture transformation and with its biomagnification decreases crop productivity in adjoining farming land (Tripathi et al., 2012, Upadhyaa et al., 2017).

Chromium is a priority pollutant (Mishra et al., 2010) and generally stable in the form of $\mathrm{Cr}(\mathrm{VI})$ and $\mathrm{Cr}(\mathrm{III})$ in nature. $\mathrm{Cr}(\mathrm{VI})$ compounds are highly toxic due to their solubility in water, permeability through cell membranes and subsequently affect protein and nucleic acids of the biological systems as compared to $\mathrm{Cr}$ (III) (Wuana and Okieimen, 2011; Sultan and Hasnain, 2005). In addition, $\mathrm{Cr}(\mathrm{VI})$ is a well-known mutagenic (Gili et al., 2002) and carcinogenic (Codd et al., 2003) 
agent that causes DNA damage (Chen and Hao, 1998) and reduces soil fertility and plant growth (Ahemad, 2015). The conventional methods for treatment of $\mathrm{Cr}(\mathrm{VI})$ pollution are not environmental friendly. Thus, it is imperative to look into ecofriendly and economic alternatives where, microbial detoxification seems to be a most plausible approach. Microbes with higher resistance or tolerance to $\mathrm{Cr}(\mathrm{VI})$ are the potential candidate for detoxification of $\mathrm{Cr}(\mathrm{VI})$. A wide array of bacteria belonging to several genera Aceinetobacter, Serratia, Bacillus, Pantoea, Pseudomonas, Staphylococcus, Cellulomonas, Achromobacter, Micrococcus, Escherichia, Ochrobactrum, isolated from chromium contaminated sites, have shown biotransformation especially reduction of $\mathrm{Cr}(\mathrm{VI})$ to relatively nontoxic $\mathrm{Cr}$ (III) (Mishra et al., 2010; Kathiravan et al., 2010).

In this context, the prime concern is to reclaim and restore soil properties through the process of microbial bioremediation (Hansda et al., 2014). Soil is the source of nutrients to the plant and harbors microbes performing various activities essential for maintenance of soil fertility. Such activities of soil microbes are largely affected by pollutants released to the soil, as plant growth is regulated by soil fertility (Hansda et al., 2014). Several studies have reported the utilization of plant growth promoting rhizobacteria (PGPR) for the bioremediation of toxic metals (Samuel et al., 2013; Sobariu et al., 2016; Ndeddy and Babalola, 2016).

However, exploration of efficient $\mathrm{Cr}(\mathrm{VI})$ reducing bacteria having phosphate solubilization, nitrogen fixation and potash solubilization activity is a crucial need for the bioremediation of $\mathrm{Cr}(\mathrm{VI})$ as well as increasing nutrient availability of contaminated soils. With this background, the present study is envisaged to explore potential chromium resistant or reducing and NPK activity showing bacteria from Sukinda mining area for bioremediation of $\mathrm{Cr}(\mathrm{VI})$ contaminated soil.

\section{Materials and Methods}

\section{Sampling and physico-chemical parameter analysis}

For this study, five different sites, IMFA, Jindal mines, Kamardha mines, Dumsala canal and OMC Ltd. were selected in the Sukinda mining area of district Jajpur, Odisha, located between latitudes $21^{\circ} 00^{\prime} 07^{\prime}$ ' to $21^{\circ} 02^{\prime}$ ' $46^{\prime \prime} \mathrm{N}$ and longitudes $85^{\circ} 44^{\prime} 12^{\prime \prime}$ to $85^{\circ} 47^{\prime} 22^{\prime \prime} \mathrm{E}$. The water, sediment, sludge and overburden soil samples were collected using sterile containers and processed in the laboratory for physico-chemical parameter and bacteriological analysis. Different physiochemical parameters such as $\mathrm{pH}$, temperature, moisture, electrical conductivity (EC), total dissolve solid (TDS) were analyzed by standard method. Moreover, total and Cr(VI) content of the samples were analyzed by APHA method using AAS (Das et al., 2013). The chemicals and reagents used in the research work were procured from Hi-Media Laboratories Pvt. Ltd.

\section{Isolation and screening of $\mathrm{Cr}(\mathrm{VI})$ resistant bacteria}

The aerobic, heterotrophic bacteria were isolated using Lauria Bertani (LB) agar medium supplemented with $100 \mathrm{mg} / \mathrm{l}$ of filter $(0.22 \mu \mathrm{m}) \quad$ sterilized $\quad \mathrm{K}_{2} \mathrm{CrO}_{4} \quad$ solution employing serial dilution followed by spread plate technique. The colonies of distinct morphological characters were individually picked up, sub-cultured and preserved in glycerol stock at $-80^{\circ} \mathrm{C}$ for further use. Then, the extent of $\mathrm{Cr}(\mathrm{VI})$ tolerance or resistance of bacterial isolates were conducted with increasing (100-3500 mg/l) concentrations of $\mathrm{Cr}(\mathrm{VI})$ on LB agar plates and the chromium 
tolerance or resistance pattern of bacterial strains were noted down (Mishra et al., 2010).

\section{Morpho-physiological characterization of $\mathrm{Cr}(\mathrm{VI})$ resistant bacteria}

The morpho-physiological characteristics of $\mathrm{Cr}(\mathrm{VI})$ resistance bacterial strains were determined by their colony morphology on LB agar and Gram's reactions with light microscopic imaging. Bacterial isolates were then processed for generic level identification by the standard methods of biochemical, enzymatic, sugar utilization and antibiotic sensitivity tests as prescribed by Bergy's Manual of Determinative Bacteriology (Holt et al., 1994). Then, the obtained results were interpreted with the ABIS online software and the bacterial strains were provisionally identified up to genus level.

\section{Evaluation of N-fixation, phosphate- potassium solubilization of $\mathrm{Cr}(\mathrm{VI})$ resistant bacteria}

The $\mathrm{Cr}(\mathrm{VI})$ resistant bacterial strains were then subjected to nitrogen fixation, phosphate and potassium solubilization. Briefly these bacterial strains were inoculated to nitrogen free medium like Jansen agar medium and incubated at $30 \pm 1^{\circ} \mathrm{C}$ for 72 hours (Pahari and Mishra, 2017). The nitrogen fixing ability of bacterial strains was observed from growth of the bacteria on the medium. Following nitrogen fixation, these bacterial strains were also inoculated to Pikovskaya agar and Aleksandrov agar medium and incubated at $27^{\circ} \mathrm{C}$ for 7 days.

Then, the halozone formed around colonies were measured and the solubility index (SI) for phosphate $(\mathrm{P})$ and potassium $(\mathrm{K})$ was calculated by the following formulae (Mursyida et al., 2015); Solubility index = [halozone diameter $(\mathrm{mm})$ - colony diameter $(\mathrm{mm})$ ] / colony diameter $(\mathrm{mm})$.

\section{Results and Discussion}

\section{Physico-chemical parameter analysis}

The microbial diversity of chromite mines or contaminated sites depends upon several factors such as $\mathrm{pH}$, temperature, trivalent or hexavalent chromium concentration and rainfall. These microbes have developed the ability to tolerate and reduce chromium and can be used for detoxification of hexavalent chromium contaminated sites. The physicochemical parameters analysis of the mines sample (Table 1) revels, the $\mathrm{pH}$ of water, sediment, sludge and overburden samples were $7.8,7.32,7.31$, and 7.69 respectively. The $\mathrm{pH}$ of water, sediment, sludge and overburden soil samples of Sukinda mining area is almost alkaline in nature. The alkaline $\mathrm{pH}$ of chromium contaminated sites due to presence of high amount of chromium, which is generally stable in alkaline $\mathrm{pH}$ and hexavalent chromium is dominant in such aqueous environment at $\mathrm{pH} 6.5$ to 9 (Mishra et al., 2010). The hexavalent chromium content in water, sediment, sludge and overburden soil samples were $1.230 \mathrm{mg} / \mathrm{L}$, $713 \mathrm{mg} / \mathrm{kg}, 350 \mathrm{mg} / \mathrm{kg}$, and $938 \mathrm{mg} / \mathrm{kg}$ respectively.

The average hexavalent chromium content of the water samples of the mining area was $1.230 \mathrm{mg} / \mathrm{L}$ which far exceeds the prescribed EPA standards of $0.05 \mathrm{mg} / \mathrm{l}$ (APHA, 2005). The total chromium content of water, sediment, sludge and overburden soil samples were $2.54 \mathrm{mg} / \mathrm{L}, 6900 \mathrm{mg} / \mathrm{kg}, 3400 \mathrm{mg} / \mathrm{kg}$, $7300 \mathrm{mg} / \mathrm{kg}$ respectively. Moreover, presence of such high levels of hexavalent chromium in the water, sediment, sludge and overburden soil can be attributed to high mining activity vis-a-vis release of untreated waste water from mines, rainwater running off the overburden and dumps collapsing and mixing with water in the river (Das et al., 2013; Mishra et al., 2010). 


\section{Isolation and screening of $\mathrm{Cr}(\mathrm{VI})$ resistant bacteria}

The total aerobic, heterotrophic bacteria in the water and sediment, sludge and overburden soil samples were $8.9 \times 10^{4} \mathrm{CFU} / \mathrm{ml}, 8.4 \times 10^{4}$ CFU/gm, $2.16 \times 10^{4} \mathrm{CFU} / \mathrm{gm}$ and $1.26 \times 10^{4}$ $\mathrm{CFU} / \mathrm{gm}$ respectively. In to 25 bacteria were isolated, among them 14 isolates showed resistance (Table 2) towards higher concentration of hexavalent chromium. Ten bacterial isolates showed resistance to $1500 \mathrm{ppm}$ of hexavalent chromium concentration. Moreover, bacterial isolates such as CTSI-01, CTWI-03 and CTWI-06 were able to tolerate $3500 \mathrm{ppm}$ of hexavalent chromium concentration. Such higher level of hexavalent chromium resistance might be due to molecular adaptation of bacterial isolates in the chromium contaminated sites and the difference in resistance pattern indicating to variation of $\mathrm{Cr}(\mathrm{VI})$ concentration in the particular area (Mishra et al., 2010; Ilias et al., 2011).

\section{Morpho-physiological characterization of $\mathrm{Cr}(\mathrm{VI})$ resistant bacteria}

The Gram variability reactions revealed that amongst 14 chromium resistant bacteria, 08 were Gram positive rods and 06 were Gram positive cocci (Table 3 ). The $\mathrm{Cr}(\mathrm{VI})$ resistant bacteria showed urease, lipase and catalase enzymatic activity, however a negative trend in gelatinase and cellulase enzyme activity was observed by these bacterial isolates. Nevertheless, few bacterial isolates showed positive to caseinase, amylase and DNAase enzyme.

Moreover, sugar utilization results of $\mathrm{Cr}(\mathrm{VI})$ resistant bacterial isolates concluded that, most of the bacteria were able to assimilate maltose, fructose, dextrose, L-arabinose, mannose, cellobiose and very few bacterial isolates were able to utilized other sugars used in the study.

The bacterial isolates were affiliated to the genus such as Bacillus, Paenibacillus, Brevibacillus, Acinetobacter, Enterobacter, Micrococcus and Staphylococcus by morphophysiological characterizations.

In contrast to our observation, chromium resistant bacteria belonging to the same genera were also reported by most of the researcher (Ankita and Saharan, 2017; Das et al., 2013) while working on $\mathrm{Cr}$ (VI) chromium reduction.

Table.1 Physico-chemical parameter analysis of mines sample

\begin{tabular}{|c|c|c|c|c|c|c|c|}
\hline Samples & $\mathbf{p H}$ & $\begin{array}{c}\text { Temp. } \\
\left({ }^{\mathbf{0}} \mathbf{c}\right)\end{array}$ & $\begin{array}{c}\text { Moisture } \\
(\boldsymbol{\%})\end{array}$ & $\begin{array}{c}\mathbf{E C} \\
(\boldsymbol{\mu S} / \mathbf{c m})\end{array}$ & $\begin{array}{c}\text { TDS } \\
(\mathbf{p p m})\end{array}$ & $\begin{array}{c}\text { Total Cr } \\
(\mathbf{m g} / \mathbf{L})\end{array}$ & $\begin{array}{c}\mathbf{C r}(\mathbf{V I}) \\
(\mathbf{m g} / \mathbf{L})\end{array}$ \\
\hline Water & 7.8 & 35 & -- & 260 & 0.10 & 2.54 & 1.230 \\
\hline Sediment & 7.32 & 38 & 12.5 & 58 & 0.00 & 6900 & 713 \\
\hline Sludge & 7.31 & 35 & 35 & 387 & 0.10 & 3400 & 350 \\
\hline OB Soil & 7.69 & 37 & 25 & 61 & 0.00 & 7300 & 938 \\
\hline
\end{tabular}


Table.2 Hexavalent chromium tolerance by bacterial isolates

\begin{tabular}{|c|c|c|c|c|c|c|c|}
\hline $\begin{array}{c}\text { Isolates } \\
\text { code }\end{array}$ & $\begin{array}{c}\mathbf{5 0 0} \\
\mathbf{p p m}\end{array}$ & $\begin{array}{c}\mathbf{1 0 0 0} \\
\mathbf{p p m}\end{array}$ & $\begin{array}{c}\mathbf{1 5 0 0} \\
\mathbf{p p m}\end{array}$ & $\begin{array}{c}\mathbf{2 0 0 0} \\
\mathbf{p p m}\end{array}$ & $\begin{array}{c}\mathbf{2 5 0 0} \\
\mathbf{p p m}\end{array}$ & $\begin{array}{c}\mathbf{3 0 0 0} \\
\mathbf{p p m}\end{array}$ & $\begin{array}{c}3500 \\
\text { ppm }\end{array}$ \\
\hline CTSI-01 & +++ & +++ & ++ & ++ & ++ & + & + \\
\hline CTSI-02 & +++ & ++ & + & -- & -- & -- & -- \\
\hline CTSI-03 & + & -- & -- & -- & -- & -- & -- \\
\hline CTSI-04 & ++ & -- & -- & -- & -- & -- & -- \\
\hline CTSI-05 & ++ & + & -- & -- & -- & -- & - \\
\hline CTSI-06 & ++ & + & -- & -- & -- & -- & -- \\
\hline CTSI-07 & +++ & ++ & + & -- & -- & -- & -- \\
\hline CTWI-01 & +++ & ++ & + & -- & -- & -- & -- \\
\hline CTWI-02 & +++ & ++ & + & -- & -- & -- & -- \\
\hline CTWI-03 & +++ & +++ & ++ & ++ & ++ & + & + \\
\hline CTWI-04 & +++ & +++ & ++ & ++ & + & -- & -- \\
\hline CTWI-05 & +++ & +++ & ++ & ++ & + & -- & -- \\
\hline CTWI-06 & +++ & +++ & +++ & ++ & ++ & + & + \\
\hline CTWI-07 & +++ & ++ & + & + & -- & -- & -- \\
\hline
\end{tabular}

Table.3 Biochemical characterization of $\mathrm{Cr}(\mathrm{VI})$ resistant bacterial isolates

\begin{tabular}{|c|c|c|c|c|c|c|c|c|c|c|c|c|c|}
\hline Isolates code & $\mathbf{1}$ & $\mathbf{2}$ & $\mathbf{3}$ & $\mathbf{4}$ & $\mathbf{5}$ & $\mathbf{6}$ & $\mathbf{7}$ & $\mathbf{8}$ & $\mathbf{9}$ & $\mathbf{1 0}$ & $\mathbf{1 1}$ & $\mathbf{1 2}$ & $\mathbf{1 3}$ \\
\hline CTSI-01 & + ve rods & - & + & - & - & + & - & - & + & - & + & + & + \\
\hline CTSI-02 & + ve cocci & - & - & - & - & - & - & - & - & - & - & - & + \\
\hline CTSI-03 & + ve rods & - & - & - & + & - & - & - & - & - & - & + & + \\
\hline CTSI-04 & + ve rods & - & - & - & - & + & - & - & + & + & + & - & + \\
\hline CTSI-05 & + ve rods & - & - & + & - & + & - & - & + & + & + & - & + \\
\hline CTSI-06 & + ve cocci & - & + & - & - & - & - & - & - & - & - & - & + \\
\hline CTSI-07 & + ve rods & - & - & - & + & + & + & - & - & - & - & - & + \\
\hline CTWI-01 & + ve cocci & - & - & - & - & - & - & - & - & + & - & - & + \\
\hline CTWI-02 & + ve rods & - & - & - & - & + & + & - & + & + & + & + & + \\
\hline CTWI-03 & + ve cocci & - & + & + & - & + & + & + & + & - & + & - & + \\
\hline CTWI-04 & + ve rods & - & + & - & - & + & - & - & + & - & - & - & + \\
\hline CTWI-05 & + ve rods & - & + & - & - & + & - & - & - & - & - & + & + \\
\hline CTWI-06 & + ve rods & - & - & + & + & + & + & - & + & - & + & - & + \\
\hline CTWI-07 & + ve cocci & - & + & - & + & - & - & - & - & - & - & - & + \\
\hline
\end{tabular}

NB: 1. Gram Staining 2. Indole, 3. MR, 4. VP, 5. Citrate, 6. Esculin, 7. ONPG, 8. Gas, 9. Mannitol, 10. Motility, 11.

Nitrate Broth, 12. Oxidase, 13. Catalase 
Table.4 Evaluation of NPK activity of Cr(VI) resistant isolates

\begin{tabular}{|l|c|c|c|}
\hline \multicolumn{1}{|c|}{ Bacteria } & $\begin{array}{c}\text { Nitrogen } \\
\text { fixation }\end{array}$ & $\begin{array}{c}\text { Phosphate } \\
\text { solubilization (SI) }\end{array}$ & $\begin{array}{c}\text { Potassium } \\
\text { solubilization (SI) }\end{array}$ \\
\hline Paenibacillus sp. CTSI-01 & + & - & - \\
\hline Staphylococcus sp. CTSI-02 & + & - & - \\
\hline Bacillus sp. CTSI-03 & + & - & - \\
\hline Bacillus sp. CTSI-04 & + & - & - \\
\hline Brevibacillus sp. CTSI-05 & + & - & 1 \\
\hline Micrococcus sp. CTSI-06 & + & 1 & - \\
\hline Bacillus sp. CTSI-07 & + & - & - \\
\hline Staphylococcus sp. CTWI-01 & + & - & 1.2 \\
\hline Bacillus sp. CTWI-02 & + & - & - \\
\hline Micrococcus sp. CTWI-03 & + & - & - \\
\hline Bacillus sp. CTW I-04 & + & - & 1.3 \\
\hline Brevibacillus sp. CTW I-05 & + & - & 0.83 \\
\hline Enterobacter sp. CTWI-06 & + & 0.57 & - \\
\hline Acinetobacter sp. CTWI-07 & + & 1 & - \\
\hline
\end{tabular}

\section{Evaluation of NPK activity of $\mathrm{Cr}(\mathrm{VI})$ resistant bacteria}

Interestingly, amongst 14 chromium resistant bacterial isolates, three isolates such as Micrococcus sp. CTSI-06, Enterobacter sp. CTWI-06 and Acinetobacter sp. CTWI-07 depicted nitrogen fixation, phosphate and potassium solubilization capability as revealed from solubility index (Table 4). Moreover, several studies have reported utilization of chromium resistant and plant growth promoting rhizobacteria (PGPR) for the bioremediation of toxic metals (Samuel et al., 2013; Sobariu et al., 2016; Ndeddy and Babalola, 2016) to reclaim and restore soil properties.

In conclusion, the locally isolated strains showed higher tolerance or resistance to $\mathrm{Cr}$ (VI) as well as nitrogen fixation, phosphate and potassium solubilization capability. The advantages of selecting suitable native bacterial strains from Sukinda mining area for bioremediation purpose to minimize inhibitory effects of other co-contaminant present with chromium. Thus, these potential chromium resistant and NPK activity showing locally isolated bacterial strains may be used for detoxification of $\mathrm{Cr}(\mathrm{VI})$ as well as to increase nutrient availability of chromium contaminated soils. Further research is highly indispensible to study the hexavalent chromium reduction potentiality of the bacterial isolates.

\section{Acknowledgments}

Financial support of the Science and Technology Department, Government of Odisha, Bhubaneswar is thankfully acknowledged. Moreover, the authors are thankful to Central Instrumentation Facility, OUAT, Bhubaneswar for providing laboratory facilities to conduct the research work. The authors have no conflict of interest to declare.

\section{References}

Ahemad, M. 2015. Enhancing phytoremediation of chromiumstressed soils through plant-growthpromoting bacteria. Jour. Genetic Eng. 
Biotech., 13: 51-58. doi: 10.1016/j.jgeb.2015.02.001

Ankita and Saharan, B.S. 2017. Luteimonas aestuarii SA13A as a novel chromium reducing strain isolated from tannery effluent. Int. J. Curr. Microbiol. App. Sci. 6(4): 1014-1022. doi: https://doi.org/10.20546/ijcmas.2017.6 04.126

APHA. Standard methods for the examination of water and waste water [S]. Washington DC: American Public Health Association, 2005.

Holt, J.G., Krieg, N.R., Sneath, P.H.A., Staley, J.T., Williams, S.T. (ed): 1994. Bergey's Manual of Determinative Bacteriology, 9th edn. Williamsons and Wilkins, Balitomore.

Chen, J.M. and Hao, O.J. 1998. Microbial chromium(VI) reduction. Crit. Rev. Environ. Sci. Technol., 28: 219-251.

Codd, R., Irwin, J.A. and Lay, P.A. 2003. Sialoglycoprotein and carbohydrate complexws in chromium toxicity. Curr. Opi. Chem, Biol., 17(2): 213219.

Das, S., Patnaik, S.C., Sahu, H.K., Chakraborty, A., Sudarshan, M., and Thatoi, H. N. 2013. Heavy metal contamination, physico-chemical and microbial evaluation of water samples collected from chromite mine environment of Sukinda, India. Trans. Nonferrous Met. Soc. China, 23: 484-493.

Das, S., Mishra, J., Das, S.K., Pandey, S., Rao, D.S., Chakraborty, A., Sudarshan, M., Das, N. and Thatoi, H. 2014. Investigation on mechanism of $\mathrm{Cr}(\mathrm{VI})$ reduction and removal by Bacillus amyloliquefaciens, a novel chromate tolerant bacterium isolated from chromite mine coil. Chemosphere, http://dx.doi.org/10.1016/j.chemospher e.2013.08.080.
Gili, P., Medeiros, A., Lorenzo-LorenzoLouis, P.A., de la Rosa, E.M. and Munoz, A. 2002. On the interaction of compounds of chromium(VI) with hydrogen peroxide; A study of chromium(VI) and (V) peroxides in the acid-basic $\mathrm{pH}$ range. Inorganica Vhimica Acta., 331(1): 16-24.

Hansda, A., Kumar, V., Anshumali, A. and Usmani, Z. 2014. Phytoremediation of heavy metals contaminated soil using plant growth promoting rhizobacteria (PGPR): a current perspective. Recent Res. Sci. Technol., 6: 131-134.

Ilias, M., Rafiqullah, I.M., Debnath, B.C., Mannan, K.S.B., and Hoq, M.M. 2011. Isolation and characterization of chromium(VI) reducing bacteria from tannery effluents. Indian J. Microbiol., 51: 76-81.

Kathiravan, M.N., Karthick, R., Muthu, N., Muthukumar, K., and Velan, M. 2010. Sonoassisted microbial reduction of chromium. Appl. Biochem. Biotechnol., 160: 2000-2013.

Mishra, V., Samantary, D.P., Dash, S.K., Mishra, B.B. and Swain, R.K. 2010. Study on hexavalent Chromium reduction by Chromium resistant bacterial isolates of Sukinda mining area. Our Nature, 8(1): 63-71.

Mursyida E., Mubarik N. R. and Tjahjoleksono A. 2015. Selection and identification of phosphate-potassium solubilizing bacteria from the area around the limestone mining in cirebon quarry. Res. J Microbio., 10: 270-279.

Ndeddy Aka, R.J. and Babalola, O.O. 2016. Effect of bacterial inoculation of strains of Pseudomonas aeruginosa, Alcaligenes faecalis and Bacillus subtilis on germination, growth and heavy metal $(\mathrm{Cd}, \mathrm{Cr}$, and $\mathrm{Ni})$ uptake of Brassica juncea. Int. J. Phytoremediation, 18: 200-209. doi: 10.1080/15226514.2015.1073671 
Pahari, A., and Mishra, B.B. 2017. Characterization of siderophore producing rhizobacteria and its effect on growth performance of different vegetables. Int. J. Curr. Microbiol. App. Sci. 6(5): 1398-1405. doi: https://doi.org/10.20546/ijcmas.2017.6 05.152

Samuel, J., Paul, M.L., Ravishankar, H., Mathur, A., Saha, D.P. and Natarajan, C. 2013. The differential stress response of adapted chromite mine isolates Bacillus subtilis and Escherichia coli and its impact on bioremediation potential. Biodegradation, 24: 829-842. doi: 10.1007/s10532-013-9631-8.

Sobariu, D.L., Fertu, D.I.T., Diaconu, M., Pavel, L.V., Hlihor, R.M. and Drãgoi, E.N. 2016. Rhizobacteria and plant symbiosis in heavy metal uptake and its implications for soil bioremediation. N. Biotech., doi: 10.1016/j.nbt.2016.09.002.

Sultan, Hasnain, 2005. Isolation of hexavalent chromium-reducing Cr-tolerant facultative anaerobes from tannery effluent. J. Gen. Appl. Microbiol., 47: 307-312.

Tripathi, D.K., Singh, V.P., Kumar, D., and Chauhan, D.K. (2012). Impact of exogenous silicon addition on chromium uptake, growth, mineral elements, oxidative stress, antioxidant capacity, and leaf and root structures in rice seedlings exposed to hexavalent chromium. Acta Physiol. Plant., 34: 279-289. doi: 10.1007/s11738-0110826-5.

Upadhyay, N., Vishwakarma, K., Singh, J., Mishra, M., Kumar, V., Rani, R., Mishra, R.K., Chauhan, D.K., Tripathi, D.K. and Sharma, S. 2017. Tolerance and reduction of chromium(vi) by Bacillus sp. Mnu16 isolated from contaminated coal mining, Soil Front. Plant Sci., 8: 1-8.

Wuana, R.A. and Okieimen, F.E. 2011. Heavy metals in contaminated soils: a review of sources, chemistry, risks and best available strategies for remediation. ISRN Ecol., 1-20. doi: 10.5402/2011/402647.

\section{How to cite this article:}

Pattnaik, S., D. Dash and Samantaray, D.P. 2017. Exploration of NPK Activity Showing Chromium Resistant Bacteria from Sukinda Mining Area. Int.J.Curr.Microbiol.App.Sci. 6(12): 535-542. doi: https://doi.org/10.20546/ijcmas.2017.612.065 